No 5(68), 2020, pp. 129-156

https://doi.org/10.12797/Politeja.17.2020.68.07

\author{
Jakub K. GÓRKA (D)
}

jakubkamilgorka@gmail.com

\title{
THE POPULIST IDENTITY \\ OF THE PROMOTERS \\ OF ALTERNATIVE MEDICINE ${ }^{1}$
}

ABSTRACT In this paper, the author compares phenomena of political populism and alternative medicine on the ground of - similar in structure and content - narrations (and identities created on their basis) of propagators and followers of these ideas/social praxis. The main thesis of the paper is the assumption that the narrative and identity mechanisms of alternative medicine are analogous to those of political populism. The author tries to prove it in the context of their relation to their counterparts in the mainstream of power/knowledge, with the assumption that these are dialectical relations understood in a specific manner. The oppositions of populism-liberal democracy and alternative medicine-conventional medicine are real, but in the broader sense, they complement and need each other to preserve the cores of the system, which implicates ineffectiveness of those alternative discourses. This article presents examples of anti-elitism and conspiratorial thinking both in political populism and in alternative medicine. It turns out that populism and unconventional medicine are so closely connected that alternative medicine, in its attitudes, refers not only to medical statements, but also to political ones.

Keywords: populism, identity, alternative medicine, anti-elitism

\footnotetext{
1 Many thanks to Professor Kamil Minkner (University of Opole) for substantive support in writing the article.
} 


\section{POPULISM AND DIALECTICAL CREATION OF IDENTITY}

The victory of Prawo i Sprawiedliwość ('Law and Justice') and its coalition partners in 2015 parliamentary elections, the Brexit referendum and the victory of Donald Trump in the US presidential election are considered as a prelude to the populist revival in modern democratic politics. ${ }^{2}$ Taking a closer look at the subject of populism, Roger Eatwell and Matthew Goodwin point out that populism has a long tradition of being present in the political culture of Western civilization, and is by no means a new and seasonal phenomenon - therefore it should be considered in a broader time perspective. ${ }^{3} \mathrm{Jan}$-Werner Müller goes even further in his considerations and posits that populism is a shadow of representative politics, ${ }^{4}$ outlining relational perspective in the analysis of populism. Thus, we can speak of a permanent relationship between democracy and populism, which is even dialectical in its nature, if one recognizes that the assumptions and goals of democracy and populism are opposite. This relation can be analysed by means of the methodology used by Kamil Minkner to study political nature of conspiracy theories. ${ }^{5}$ In this dialectical perspective, democracy - as the mainstream of politics - would be an element dominating populism, being its Müllerian shadow which undermines, inherently imperfect, democratic method of organizing society, which is, like any other phenomenon, incomplete. ${ }^{6}$ This relation should be seen as one phenomenon or a certain system, and not two separate ones, occurring incidentally. Therefore, populism is the Minknerian paradoxical component of liberal democracy. ${ }^{7}$ On a similar note, Maciej Gdula considers neoliberal context of populism and states that Neoliberal policies led to the creation of economic frustration expressed in populism, which in turn deepened the creation of new layers of economic frustration channelled into populist rhetoric. ${ }^{8}$

According to Gdula, the relation between neoliberalism and populism is a certain perpetum mobile. Neoliberalism, through its unreliable mechanisms, creates an internal enemy, which, although illusory from the perspective of the entire system, channels social discontent in such a skilful manner that the foundations of neoliberalism are not ultimately undermined. At the same time, as important from the dialectical perspective assuming mutual conditioning, ${ }^{9}$ populism, apart from its function of a channel of

2 M. Marchlewska et al., "Populism as Identity Politics: Perceived Ingroup Disadvantage, Collective Narcissism and Support for Populism”, Social Psychological and Personality Science, vol. 9, no. 2 (2017), pp. 151-162, p. 3.

3 R. Eatwell, M. Goodwin, Narodowy populizm. Zamach na liberalna demokracje, Katowice 2020, p. 20.

4 J.-W. Müller, Co to jest populizm?, Warszawa 2017.

5 K. Minkner, "Polityczność teorii spiskowych", in M. Mikołajczyk, M. Karwat (eds.), Politologii model krytyczny, Kraków 2017.

6 Ibid., p. 92.

7 Ibid., p. 93.

8 M. Gdula, Nowy autorytaryzm, Warszawa 2018, p. 14.

$9 \quad$ K. Minkner, “Polityczność...”, p. 91. 
social frustration, is a touchstone of social dissatisfaction with the exercise of power in liberal democracy. ${ }^{10}$ In an even broader, civilizational perspective, it may be an expression of social dissatisfaction with the trends affecting today's societies.

In the context of the concept of identity, which is of key importance to this article, populism is always a form of identity politics, ${ }^{11}$ which emphasizes the inseparability of identity issues and political populism. Chantal Mouffe points out that neoliberalism, to which populism at least declaratively opposes, does not only mean a specific economic policy within liberal democracy, but also a comprehensive concept of society and the individual based on the philosophy of possessive individualism. ${ }^{12}$ Therefore, in order to secure and strengthen its economic interests, neoliberalism tries to strengthen its cultural hegemony by forming an individual human identity, the ideal type of which is homo economicus. This means that for populist formations, the leitmotif is the reactive construction and strengthening of group identities, especially the identities of national and ethnic groups, in opposition to the individualist identity created by the neoliberal system. To weaken the influence of neoliberalism in society, in order to strengthen their own position, populists are forced to create and offer their own identities, because winning on the economic level may not be enough for the triumph of populism.

Thanks to having both an individual and collective identity, it is possible to achieve consistency, but also to distinguish oneself from others. ${ }^{13}$ Identity, in fact, 'enables' another buman..., ${ }^{14}$ which highlights the role of the figure of the Other in identity shaping. According to the author, identity/identities are built from interconnected narratives. Thus, political identities are in this sense built from political narratives, while medical identities are based mainly on narratives about medicine, but - as it will be demonstrated later - also on political narratives. According to Anthony Giddens, sustaining a narrative is a condition for maintaining identity, ${ }^{15}$ and Grzegorz Ptaszek even claims that man is by nature a narrative being. ${ }^{16}$ In his opinion, the narratives allow you to understand the surrounding reality, organize it and define your place in this story. ${ }^{17}$ Thus, the populist and alternative medicine identity is the sum of the narratives about the human being as a political and biological (medical) identity established in the process of social communication and recognized as its "own" by the individual. The concept of narrative applies to any verbal and non-verbal attempt to make a person believe something or act in

10 A. Wołek, "Jak polskie elity oswoiły populizm”, Ośrodek Myśli Politycznej, at <https://omp.org.pl/ artykul.php?artykul=281\#_ftn11>,29 October 2020.

11 J.-W. Müller, Co to jest populizm?..., p. 18.

12 C. Mouffe, Wobronie lewicowego populizmu, Warszawa 2020, p. 17.

13 K. Waszczyńska, “Wokół problematyki tożsamości”, Rocznik Towarzystwa Naukowego Ptockiego, no. 6 (2014), p. 53.

14 K. Kwapis, E. Brygoła, “Tożsamość osobista w ujęciu emotywno-refleksyjnym: zawartość, funkcje i procesy kształtowania tożsamości”, Opuscula Sociologica, vol. 4, no. 6 (2013), p. 34.

15 A. Giddens, Nowoczesność i tożsamość, Warszawa 2006, p. 77.

16 G. Ptaszek, "Wróżba (telewizyjna) jako narracja. Prolegomena", in J. Wasilewski (ed.), Narracje w życiu. O grupie i jednostce, Warszawa 2016, p. 120.

17 Ibid. 
a certain way. ${ }^{18}$ The persuasive function of language, indicated by many as primary, has its source in the herd-like nature of humans. ${ }^{19}$ It would be then impossible to recognize an individual's identity in isolation from the social context. Narratives are indispensable to an individual "to live," ${ }^{20}$ but only later, in the course of social relations, are they used for persuasive purposes. Although the narratives have a fairy-tale nature, this element of subtle fictionality in the narratives does not exclude their logical structuring. ${ }^{21}$ When we add to that Aleksandra Kunce's observation that the postmodern identity seems to be filled with trifles, remnants, clutter, ${ }^{22}$ we can posit that building identity in the postmodern world consists of eclectic weaving of narratives from (not in the literal meaning) anything, just to obtain a logically structured story, absorbed by potential recipients of these messages, to whom it is supposed to provide easy-to-use and anxiety-relieving tools for interpreting complex reality. Coherent identity, as shown by psychological research, enhances the sense of inner well-being, and fragmentation of identity reduces it ${ }^{23}$ so narratives that increase coherence are more preferred and constitute identities more efficiently. In the context of these considerations on populism and alternative medicine, it should be added that these identities are built on the basis of dialectical relations within which opposing narratives collide. It should also be noted that the issues of identity in the era of social media are more fluid and discretionary than before, which increases the possibility of their content going beyond the actual social conditions. Mark Lilla argues that the Facebook model of ' $I^{\prime 24}$ depends rather on the sympathy of the individual and the willingness to assume a chosen identity, in spite of the objective structural or class conditions within which the individual functions. This corresponds to Wacław Branicki's thesis that virtuality can lead to a feeling of relativization of the real essence of personal identity, ${ }^{25}$ as it is so-constructed within the framework of language games, and not in the relation to a real object. In this way, virtually created identities can give the impression that the real world is also constantly being deconstructed and reconstructed. Populism, thanks to the conveyor belt of social media, has much greater opportunities to build often abstract narratives, which are already entirely dependent on subjective beliefs and emotions, than the hard socio-economic realities in which an individual is involved. ${ }^{26}$ This is why in political and scientific discourses we talk nowadays about post-truth. The position of Polska Akademia Nauk (Polish

\footnotetext{
18 E. Griffin, Podstawy komunikacji spotecznej, Gdańsk 2003, p. 327.

19 M. Tokarz, Argumentacja. Perswazja. Manipulacja. Wyktady z teorii komunikacji, Gdańsk 2006, p. 194.

20 B. Baszczak, “Tożsamość człowieka a pojęcie narracji”, Analiza i Egzystencja, no. 14 (2011), p. 126.

21 Ibid.

22 A. Kunce, Tożsamość i postmodernizm, Warszawa 2003, p. 121.

23 A. Pilarska, Ja i tożsamość a dobrostan psychiczny, Poznań 2012, p. 69.

24 M. Lilla, Koniec liberalizmu, jaki znamy, s. l. s. a., pp. 110-111.

25 W. Branicki, Tożsamość a wirtualność, Kraków 2009, p. 12.

26 An example may be the feeling of relative deprivation proposed by Eatwell and Goodwin in National Populism..., i.e. - as used by populists - a subjective feeling of economic anxiety when the economic situation is objectively, parametrically, favourable.
} 
Academy of Science) on the reasons for the dissemination of pseudoscientific views indicates that social media made it possible to create large networks of like-minded people. ${ }^{27}$ Political populism and medical populism, as the author perceives alternative medicine, use similar psychological mechanisms not only for the purpose of constructing identity, but also the means of communication, such as social media, which are McLuhanian message in itself (medium is the message), determining the nature of these messages.

\section{THE DIALECTICAL RELATION OF ALTERNATIVE MEDICINE AND CONVENTIONAL MEDICINE}

In order to be able to present the populist identity of alternative medicine, often referred to as unconventional medicine and pseudo-medicine, it is necessary to explain how this concept should be understood, using the explanations developed in the discourse on this phenomenon. According to Andrzej W. Nowak, the term 'unconventional medicine' is obviously very vague and it would be difficult to define it precisely. ${ }^{28}$ Nowak adopts an institutional, relational explanation, according to which he understand therapies as those that are not taught at medical universities and that are not covered by social insurance conditions..$^{29}$ Joanna Woźniak-Holecka, Katarzyna Zborowska and Tomasz Holecki, who study the phenomenon of alternative medicine in the context of cancer therapies, define it through the prism of compliance with the methodology of science. ${ }^{30}$ Anything incompatible with it is simply unconventional/alternative medicine. Luiza Nowakowska lists a whole range of synonyms that describe unprofessional methods of therapy: alternative medicine, natural medicine, complementary medicine, non-academic medicine, unconventional medicine, holistic medicine, paramedicine, and also accepts a relational distinction between professional and non-professional (i.e. alternative) medicine. ${ }^{31}$ Alternative medicine can also be better explained by indicating specific therapies or methods included in it. And so, in this context we can distinguish bioenergy therapy, lithotherapy, colour therapy, aromatherapy, urine therapy, bio resonance, auriculotherapy, biostimulation, brain coupling, iridology. ${ }^{32}$ The cited Encyklopedia PWN also provides methods from the borderline of conventional and unconventional medicine: herbal medicine, apitherapy, natural medicine, massage, gymnastics,

27 Etyczne aspekty upowszechniania pogladów nienaukowych, Komitet Etyki w Nauce Polskiej Akademii Nauk, Stanowisko 1/2020 z dnia 24 lutego 2020 r., 18 May 2020.

28 Ibid.

29 Ibid.

30 J. Woźniak-Holecka, K. Zborowska, T. Holecki, "Medycyna alternatywna jako uzupełniająca forma leczenia chorób nowotworowych w opinii pacjentów onkologicznych”, Psychoonkologia, no. 1 (2010), p. 22.

31 L. Nowakowska, "W stronę socjologii lecznictwa niemedycznego - zarys przedmiotu badań”, Hygeia Public Health, vol. 47, no. 3 (2012), p. 261.

32 "Medycyna niekonwencjonalna", in Internetowa encyklopedia PWN, at <www.encyklopedia.pwn.pl/ haslo/medycyna-niekonwencjonalna;3939273.html>, 27 February 2019. 
biological rhythms, healthy nutrition, various types of diets, homeopathy, acupuncture and acupressure. ${ }^{33}$ We need to add here the increasing popularity of anti-vaccine attitudes, which are presented by close groups and organizations, or the trend of treating diseases with dietary supplements, the market of which is growing every year, and whose effectiveness is not recognized by science.

As can be learned from the history of medicine, medical, and therefore professional (at the time) methods tried to deal with health issues since the dawn of time, ${ }^{34}$ long before the days of the father of medicine, Hippocrates. ${ }^{35}$ Zbigniew Brzeziński sees the sources of medicine contestation and, as a result, the emergence of alternative trends of knowledge, in a defect of thinking and cognition accompanying us from the dawn of history, which, in a way, according to this logic, determines the dichotomy between the existing conventional medicine and the opposition to alternative medicine arising from its imperfections, flowing from it and remaining in it. ${ }^{36}$ Therefore, the occurrence of the phenomenon of alternative medicine understood by the author as an activity that primarily challenges the knowledge and practice prevailing among representatives of medicine, should be perceived as a permanent element of the history of medicine, similarly to the political populism as a form of political expression that dates back to the times of ancient Rome and the Populares faction. The existence of alternative medicine - as an equivalent of populism - is indispensable because of the inalienable imperfection of medicine, which is ultimately only - like liberal democracy - a human activity, ${ }^{37}$ and moreover, it is part of a more general characteristic: man as inherently seeking alternative solutions. ${ }^{38}$ Similarly, political populism, thanks to the underrepresentation of the lower classes within the institutions of a democratic state, and thus declaratively of the people, can find a base of social support. The historian-sociologist of knowledge Peter Burke even writes in the context of social scientific practice about competition, conflict and exchange between the intellectual systems of academic elites and what can be called 'alternative knowledge.39 According to Brzeziński, the standard field of alternative medicine, which is homeopathy, was born precisely as a result of disagreement with the current methods of treatment. ${ }^{40}$ It was developed at a time when - as Brzeziński writes - the entire therapy so far was disqualified due to the development of scientific research methods, but in return nothing new was created. Samuel Hahnemann, founder

33 Ibid.

34 H. Matyja, "Medycyna niekonwencjonalna na granicy prawa na przykładzie 'badania żywej kropli krwi'”, Medyczna Wokanda, no. 10 (2018), p. 71.

J. Thorwald, Dawna medycyna. Jej tajemnice i potega, Warszawa 2017, p. 5.

36 T. Brzeziński, "Naturalne i niekonwencjonalne metody leczenia", in Idem (ed.), Historia medycyny, Warszawa 1995, p. 424.

37 Ibid., p. 424.

38 T. Paleczny, Kontestacja: formy buntu we wspótczesnym spoteczeństwie, Kraków 1997, at <https:// www.uj.edu.pl/documents/3337228/86fad7e3-4a88-44a5-b1d9-f669630c9084>, p. 10, 8 December 2019.

39 P. Burke, Spoteczna historia wiedzy, Warszawa 2016, p. 26.

40 T. Brzeziński, “Naturalne...”, p. 429. 
of homeopathy, tried to fill this void with his negation of the principles of science, which was not yet able to develop a new system of medicine. The conflict with the mainstream medicine is therefore a fundamental property of alternative medicine, both from the point of view of the ideological essence of this phenomenon and its historical and contemporary practice.

The author proposes, therefore, that alternative medicine and its relation to conventional medicine should be considered with their relation as a dialectical relation in mind, as this will allow to emphasize the narrative and identity schemas characteristic of populism without removing their proper context of the opposition between the elites (medical establishment/institutions) and the people (nation/patients) and the genesis of these phenomena in the imperfections of the hegemons. It is worth noting that while populism is opposed to the liberal values of the Enlightenment, and alternative medicine is against methodology and scientific ethics, both ideas they face are upheld and expressed within specific institutions. The university, that is, a scientific institution attacked by alternative medics, can be seen, following Pierre Bourdieu, as an institution socially recognized as entitled to make objectivization aspiring to objectivity and universality. ${ }^{41}$ Likewise, political populism undermines the legitimacy of claiming universality by belonging to the end of history of democratic political institutions such as political parties, parliaments or constitutional rule of law, which set the course for political action. Just as a nation does not have a direct impact on the authorities restricted by divisible and limited laws established and exercised by state institutions, patients have little influence on their treatment choices, because they must follow the authority of the medical and health service.

Ideologically, alternative medicine is closely related to a holistic approach to health. This model became popular in the 1970s as a response to the bureaucratization, engineering and iatrogenicity of contemporary medicine. ${ }^{42}$ In the literature, it is even called a social model which, as opposed to the main, specialized current, focuses on the individual as an integral part of society. ${ }^{43}$ What alternative medicine, with its "holistic" or "social" approach, is opposed to, is a biomedical model that incorporates the methods and principles of the biological sciences. ${ }^{44}$ The biomedical model is primarily focused on the disease, an individual perceives it automatically, and in addition, it favours medical technologies more than less technically advanced solutions, while reducing the importance of preventive healthcare. ${ }^{45}$ This brings to mind neoliberalism and its individualist philosophy combined with the technocratic style of managing public policies. It is opposed by a collective, "holistic" populist approach, which in the case of medicine is a holistic approach. George Engel believed that medicine has always fluctuated

\footnotetext{
41 P. Bourdieu, "Homo academicus", Praktyka Teoretyczna, vol. 7, no. 1 (2013), at <http://www.praktykateoretyczna.pl/PT_nr7_2013_NOU/03.Bourdieu.pdf>, p. 34, 7 November 2020.

42 L. Nowakowska, "W stronę socjologii..., p. 259.

43 M. Blaxter, Zdrowie, Warszawa 2009, p. 26.

44 Ibid., p. 14.

45 Ibid., p. 24.
} 
in its focus between generalized approaches and the individual being at the centre of research. ${ }^{46}$ According to him, all modern science and the model it proposes have its source in striving to understand an individual organism through learning about its parts. ${ }^{47}$ Mildred Blaxter noted that before the development of what we call Western medicine, which puts biomedicine on a pedestal, all great cultures of the world considered health as the equilibrium of the individual with respect to the environment, but also with regard to his internal processes and supernatural beings. ${ }^{48}$ In this sense, the holism of alternative medicine is a populist return to an ignored tradition and proven conservative patterns. William L. Miller and Benjamin F. Crabtree believe that the culture of biomedicine is strengthened and maintained by its good form in the prevailing cultural norms of the United States and by an elite globalizing the corporate economy. ${ }^{49}$ The essence of this ideological hegemony in mainstream medicine is based on "market myths" such as: 1) growth benefits everyone, 2) freedom is market freedom, 3) people are homo economicus, consumens et dominans, and 4) corporate globalization is inevitable. Opposition to conventional medicine must therefore take place in the economic space, giving this discourse an economic dimension. For example, structural social conditions play a role in the varying degree of use of alternative medicine. ${ }^{50}$

\section{ANTI-ELITISM OF ALTERNATIVE MEDICINE}

In order to demonstrate how narratives (and thus identities) analogous to populism are created in alternative medicine, the author selected three aspects of this phenomenon that are particularly evident in the observation of the phenomenon in alternative medicine: 1) anti-elitism, ${ }^{51}$ 2) conspiratorial thinking, ${ }^{52}$ and 3) strong distinction of one's own group as the only rightful one, as opposed to the Other/Others. Obviously, these qualities are closely interrelated and transformed in different narratives, so it is impossible to separate them. It is worth noting that the concept of strong differentiation from others is related to anti-elitism and may be stimulated by conspiratorial thinking, which is most often the case in this discourse. Conversely, conspiracy theories driving alternative-medical narratives define elite as the evil side in this dispute, hence the natural anti-elite identity of the supporters of alternative medicine.

46 Ibid., p. 42.

47 Ibid. See, for example, Engel's critique of the biomedical model to which Blaxter, inter alia, refers, G. Engel, "The Need for a New Medical Model: A Challenge for Biomedicine", Science, vol. 196, no. 4286 (1977), pp. 129-136.

48 M. Blaxter, Zdrowie..., p. 14.

49 W.L. Miller, B.F. Crabtree, "Badania kliniczne”, in N.K. Denzin, Y.S. Lincoln (eds.), Metody badań jakościowych, vol. 1, Warszawa 2014.

50 D. Hendrickson, B. Zollinger, R. McCleary, "Determinants of the Use of Four Categories of Complementary and Alternative Medicine", Complementary Health Practice Review, vol. 11, no. 1 (2006), pp. 3-26.

51 M. Marchlewska et al., "Populism...”, p. 2.

52 R. Eatwell, M. Goodwin, Narodowy populizm..., pp. 70-71. 
The most common targets for populists are the fields of economy and politics, which seems natural considering how much power is concentrated in these discourses..$^{53}$ Thus, populist anti-elitism usually targets political entities. One year before assuming power in Poland, Jarosław Kaczyński announced that there must be an elite replacement, but he did not refer to the political elite alone. ${ }^{54}$ Thus, the anti-elitism of populists can also be aimed at cultural elites. ${ }^{55}$ Although Kaczyński's narrative about the post-communist origin of the elites of the Third Polish Republic has been present in the discourse since the 1990s, after a few years of rule, feeling strong enough, he proposed to establish a new elite. Rather than a neoliberal state, it would build a genuine welfare state, ${ }^{56}$ obviously understood in conservative, paternalistic terms, supporting family under attack or otherwise populist ordinary people. Redistributive or tax policies are not homogeneous in populism because - as Pippa Norris and Ronald Inglehart point out - the most important idea of populism is anti-elitism and popular rule itself ( $w$ ho should rule); the manner of governing is secondary (that is, how something should be done). ${ }^{57}$ For that reason responses to neoliberalism and the democratic system differ. Thus, elites are closely related to the sphere of economic interests, which ultimately dictate the policy of the state, but on the other hand, a strong state may oppose them if there is sufficient determination of the representatives of the nation. A similar narrative was presented by Donald Trump when running for president in 2015. In his story, the elites are involved in the interests of global corporations. ${ }^{58}$ Consequently, a politician who has the goal of implementing the will of the people should oppose the interests of the political and economic class in favour of the interests of ordinary people. Then a new elite (super-elite) will emerge, made up of a nation and a populist leader to preside over it. In the narratives of populists, it is even said that the elites are detached from reality and that people are tired of them. ${ }^{59}$ According to its main spokesman and leader, MEP Nigel Farage, Brexit was a victory for real

53 B. Castanho Silva, F. Vegetti, L. Littvay, "The Elite Is Up to Something: Exploring the Relation Between Populism and Belief in Conspiracy Theories", Swiss Political Science Review, vol. 23, no. 4 (2017), pp. 423-443.

54 R. Wojciechowska, “Jarosław Kaczyński w Gdańsku. 'W Polsce musi nastąpić wymiana elit”, Dziennik Battycki, 26 August 2014, at <https://dziennikbaltycki.pl/jaroslaw-kaczynski-w-gdansku-w-polscemusi-nastapic-wymiana-elit-zdjecia-wideo/ar/3552847>, 7 November 2020.

55 B. de Cleen, "The Party of the People Versus the Cultural Elite: Populism and Nationalism in Flemish Radical Right Rhetoric about Artists”, JOMEC Journal, no. 9, pp. 70-91.

56 "Kaczyński: W Polsce obok elity postkomunizmu jest już nowa elita, która jest w stanie zmieniać Polskę", GazetaPrawna, 14Sempember2019, at <https://www.gazetaprawna.pl/artykuly/1430132,kaczynskiw-polsce-obok-elity-postkomunizmu-jest-juz-nowa-elita-ktora-jest-w-stanie-zmieniac-polske.html>, 7 November 2020.

57 P. Norris, R. Inglehart, Cultural Backlash. Trump, Brexit and Authoritarian Populism, New York 2018, p. 5.

58 M. Kruse, Trump Reclaims the Word 'Elite' With Vengeful Pride, 11 December 2018, at <https://www. politico.com/magazine/story/2018/11/01/donald-trump-elite-trumpology-221953>, 7 November 2020.

59 Nigel Farage: People Have Had Enough of Out of Touch Elites, 12 September 2016, at <https://www. foxbusiness.com/politics/nigel-farage-people-have-had-enough-of-out-of-touch-elites $>, 7$ November 2020. 
people, a victory for ordinary people, a victory for decent people. ${ }^{60}$ Thus, according to populists, a radical change of the establishment is needed and the replacement of the democratic-liberal meta-narrative with declarative people's meta-narrative, which, in the language of political postulates, can be translated into giving power to ordinary people and establishing a real democracy in which there is no political correctness and institutions blocking the will of the nation through check and balances mechanisms. Nevertheless, populist narratives criticizing the elite imply the emergence of a new elite, which would be formed by a group that only legitimately represents "ordinary people." ${ }^{31}$ Populism is thus anti-elitist only seemingly, as it produces new elites, which, over time, become as pragmatic as the previous ones, inhibiting the process of systemic transformations, only changing the structure of the existing contradictions, not actually removing them, which is confirmed by the dialectical approach.

Similarly, anti-elitism of alternative medicine manifests itself most often in a suspicious attitude towards medical institutions, along with political and economic institutions that are hierarchical, meritocratic, and subordinate to the imperative of profit. In fact, the identity of the supporters and proponents of alternative medicine is strongly political and economic, because medical institutions as such are conditioned by state policies. Therefore, alternative medicine apparently proposes to adopt a health-only identity. As a result, it is a complex of political and philosophical beliefs, correlating - as will be demonstrated below - with specific socio-political and economic traits. Therefore, this anti-elitism is deeply rooted in the management of common goods. As Agata Bogusz notes, one of the most important elements decreasing the authority of doctors is the impact of the capitalist system and the enormous value of money in today's society. ${ }^{62}$ Therefore, the discouragement to biomedicine and the decline in respect and trust in doctors is associated with opposition to pharmaceutical corporations (Big Pharma as the elite and a conspiracy theory), ${ }^{63}$ the political class, the state health service (institutions of the ministry of health, clinics, hospitals and doctors) or mainstream media.

One of the most famous narratives in the alternative medicine discourse is that of Rockefeller's medicine, which contains elements critical of the corporation, or even of one of the greatest capitalists in history, such as John D. Rockefeller, as well as of government institutions, including easily corrupted bureaucracy. Therefore, it broadly goes beyond the criticism of modern medicine alone. From this perspective, today's scientific medicine is a kind of a "closed system," driven by the desire for profit typical of large enterprises and political and bureaucratic elites. In the narrative about Rockefeller's medicine, of key importance is the fact that we are dealing with a figure of a powerful

60 A. Foster, Ukip leader Nigel Farage's most memorable speeches including his FAREWELL today, 16 September 2016, at <https://www.express.co.uk/news/politics/686024/Ukip-leader-NigelFarage-speeches-resignation-European-Parliament-Brexit-victory>, 7 November 2020.

61 Marchlewska et al., "Populism..., p. 3.

62 A. Bogusz, "Relacje między pacjentem a lekarzem”, in B. Płonka-Syroka (ed.), Cztowiek natura, kultura-studia z historii i antropologii medycyny i farmacji spotecznej, Wrocław 2009, p. 207.

63 See conspiracy theories about Big Pharma later in this paper. 
magnate (the Other) who decides to use his fortune to harm ordinary people, depriving them of "natural" treatments, that is, the only right ones in the eyes of alternative doctors. By creating appropriate research institutions, lobbying and eventually bribing, John D. Rockefeller won the attention of the pharmaceutical industry. As a result, only specific diseases and their symptoms are treated, while natural treatments such as herbal medicine and homeopathy, which address human health issues holistically, have been abandoned. Consequently, on the one hand, doctors are victims, but on the other hand, allies of the corrupt system: Why should there be real drugs - drugs that CURE, when we live in a system created and controlled by oligarchs and business tycoons, and not by people committed to the welfare of the patient? ${ }^{24}$

We are dealing here with a conflict between what is natural and what is artificial, which corresponds to the populist division into "ordinary people" / "real nation" and degenerated elites, artificially preserved in their leading position - just as artificial as technical, specialized medical supplies. So what is artificial, is also evil and demonic, and it fights death and life against what is natural, or good, which ultimately resists evil anyway: The only thing that stopped Rockefeller from putting his plans into practice was that that at that time in the US herbal and natural remedies were very popular. ${ }^{65} \mathrm{It}$ is from folk medicine that effective solutions to health problems should be taken, and the government should be elected from among the people/ordinary folk. A slightly different narrative of Rockefeller's medicine is employed by one of the gurus of unconventional medicine in Poland, former doctor Jerzy Jaśkowski. The figure of Rockefeller appears here in a slightly different context, indicating him initially as a vendor of medicinal oil who, in order to achieve even greater profits, sought to control other methods of treatment, such as therapy, homeopathy or osteopathy. ${ }^{66}$ In Jaśkowski's narrative, such conventional therapies as chemotherapy or preventive vaccinations are the result of corrupting the government, which allocates too little expenditure to health care and science, and is unable to recognize effective treatment methods, making the said conventional therapies equally harmful. Nevertheless, the workings of the world in Jaśkowski's narrative are similar to those in the previously cited approach, but he points out that they are not controlled by corporations or factories, but by financial elites: of course, there have been over 700 years of the so-called Financial Groups associated in the City of London Corporation. ${ }^{67}$ In order to confirm the correctness of his narrative, Jaśkowski resorted to various historical examples and interdependencies, trying to demonstrate the mechanisms behind the elites' operations, which in his view are universal, and thus can be used to interpret contemporary phenomena.

64 Jak Rockefellerowie zatozyli big pharmę i zniszczyli medycyne naturalna, at <https://www.odkrywamyzakryte.com/rockefellerowie-zniszczyli-medycyne-naturalna/>, 3 November 2020. Original spelling.

65 Ibid.

66 J. Jaśkowski, "Medycyna Rockefllerowska, czyli medycyna sądownie udowodniona", Polish Club, at <https://www.polishclub.org/2018/09/27/medycyna-rockefellerowska-czyli-medycyna-sadow nie-udowodniona/ >, 5 November 2020. In his article, he refers to Leszek Balcerowicz as Aaron Bucholtz, introducing an extremely nationalistic narrative about the Jewish origin of Polish elites. Ibid. 
This is confirmed by the previously mentioned observations about the post-modern nature of building an identity from narrative pieces that only need to be combined into a coherent story. Criticizing the modern medical system, alternative medicine provides a critical identity to the world elites, and the previously characterized technologized biomedicine only serves as an extension to their interests. It's not merely the national health systems that are bad - all global medicine is fundamentally tainted with the interests of the conspirative pharmaceutical industry. The alternative medicine narrative about the emergence of the pharmaceutical industry builds a strongly anti-elite, anti-technical, conspiratorial, pseudo-scientific identity, especially in places where it selectively treats research results, notably at the level of verifying hypotheses, which is a characteristic feature of pseudoscience. ${ }^{68}$ The elite plays the role of an omnipotent actor who freely controls the order of the world. The reductionism of this narrative ignores the fact that the Flexner Report (in the narrative of Rockefeller's medicine Abraham Flexner plays the role of a sinister scientist at the service of Rockefeller) and his model of biomedicine, although they likely contributed to the decline of confidence in doctors and ultimately undermined their authority as more focused on science and procedures than on patients, was instrumental in raising scientific standards. As Thomas J. Duffy writes on the biomedical model, all physicians have been committed to generating information and contributing to advances in medical science, assigning this task to both laboratory scientists and clinicians. ${ }^{69}$ These narratives are therefore unable to admit that the world is complex and ambiguous. Even if social institutions are reformed in the spirit of elites, the consequences are only negative, unfavourable to ordinary people. Therefore, the power-people system here is a zero-sum game between good and evil, it does not assume a win-win situation. This would explain the radicalism of alternative environments and even accusations of genocide against conventional medicine. ${ }^{70}$ Both in the struggle for health and in the political struggle, those fighting the elites can win everything or nothing, because they do not want to enrich their activities with the demands of complementary medicine or political populism; therefore there is usually no space for any compromise.

Thus, the anti-elite attitudes of the supporters of alternative medicine have different justifications, as demonstrated by the analysis of the discussed approaches to Rockefeller's medicine. Alternative medicine specialists like to point out the greed for profit motivating the actions of pharmaceutical companies. ${ }^{71}$ On the other hand, they are also able to admit that the actions of medical community may not be deliberate: scientists

68 R. Stachowski, “Karl Popper i Frank Cioffi. Dwa spojrzenia na pseudonaukę", in K. Korab (ed.), Pseudonauka. Choroba, magia czy biznes?, Warszawa 2011, p. 31.

69 T.P. Duffy, "The Flexner Report - 100 Years Later", Yale Journal of Biology and Medicine, vol. 84, no. 3 (2011), pp. 269-276, at <https://www.ncbi.nlm.nih.gov/pmc/articles/PMC3178858/>, 7 November 2020 .

70 K. Grzelak, Porównat szczepienia do ludobójstwa. Surowy wyrok dla lekarza z Łodzi, 25 May 2020, at $<$ https://www.focus.pl/artykul/porownal-szczepienia-do-ludobojstwa-surowy-wyrok-dla-lekarza-zlodzi>, 8 November 2020.

71 J. Słonecki, Zdrowie na wtasne życzenie, Katowice 2004, p. 6. 
produce medical data in excess, so inevitably they have to be lobbying later, as in this information noise they no longer have the opportunity to judge what is right and what is not. ${ }^{72}$ They are certainly guilty of the situation, but at the same time they are used to pursue other interests. Medicine also appears in the narratives of alternative medicine as completely incapacitated, as if it were held hostage by pharmaceutical companies. Large medical corporations provide doctors with all the knowledge in the form of a ready ' $m$ ush' ${ }^{73}$ so they cannot treat patients differently, unless they are outstanding individuals who can independently evaluate the system to which they belong, break free of this blindness, and challenge the interests of powerful companies, as exemplified by those doctors who adhere to the principles of alternative medicine. Still other narratives indicate that the methodology of modern medicine in general, rather than ineptitude - whether intentional or not - is the result of an "inability" to treat diseases. ${ }^{74}$ If only the holistic model was adopted, the achievements of conventional medicine could be complemented (the so-called complementary medicine postulate). Therefore, the elites lack self-reflection and the ability to change faulty paradigms, and do not insist firmly on economic rationality. Thus, the medical and scientific elites may be simultaneously aware and unaware of their flaws, act on purpose and without purpose. They can be tools of political and business elites pursuing their interests, as well as actors relatively autonomous in relation to them, but at the same time inept professionals - imposing methodological limitations upon themselves, which ultimately results in an ineffective treatment of their patients. This is reminiscent of the populist narrative from the times of the PO-PSL coalition government of Donald Tusk. According to it, the Prime Minister was incompetent and ineffective, the state governed by him was weak and incapable of any actions, while at the same time Tusk was omnipotent enough to co-organize an attack on the then president, parliamentarians, high-ranking state officials and military commanders, concealing all evidence of his wrongdoing and avoiding liability. No matter how inept or, on the other hand, dangerous the medical elite might be, they always remain a deadly enemy, pulling the strings of reality.

\section{THE CONSPIRATORIAL VIEW OF ALTERNATIVE MEDICINE}

B. Silva, F. Vegetti and L. Littvay hypothesize that the conspiratorial vision of the populist world divided into sinister conspirators and their helpless victims has its source in nothing else but anti-elitism..$^{75}$ In his famous 1964 essay Paranoid Style of American Politics, Richard Hofstader noted that conspiracy theories systematize the sense of being persecuted, which is their main core. ${ }^{76}$ The paranoid style manifests itself in a sense

72 R. Wolf, Paleo dieta, Poznań 2010, p. 34.

73 J. Zięba, Ukryte terapie. Czego ci lekarz nie powie, part 1, Rzeszów 2015, p. 36.

74 M. Tombak, Uleczyć nieuleczalne, part 1, Łódź 2000, pp. 87-88.

75 B. Castanho Silva, F. Vegetti, L. Littvay, "The Elite...”.

76 R. Hofstadter, The Paranoid Style in American Politics and Other Essays, New York 1965, p. 4. 
of conspiracy against an entire nation, culture or way of life. Lech Zdybel emphasises historiosophical models in the discourses on conspiracy theories, which clearly manifest an articulated, dualistic ("Manichean") vision of the world, ${ }^{77}$ that is, a strong opposition between the society and the conspiratorial group, which results in radical antielitism. Zdybel quotes Janusz Tazbir, who believed that conspiratorial vision of history should be understood as belief in the omnipotence of certain associations, acting openly or clandestinely, but always to the detriment of someone. ${ }^{78}$ Conspiracies are, therefore, undetected publicly, otherwise they would not be conspiracies, but at the same time they are detectable by the proponents of the claims of their existence. Experimental research on psychology of conspiratorial thinking has demonstrated a relationship between an individual's lack of a sense of control and a tendency to believe in conspiracy theories. ${ }^{79}$ Someone who feels fear and lack of control over what is happening around him is more likely to believe in the existence of a secret group conspiring against society and harming it (and, therefore, the individual in question).

One of the most widespread conspiracy theories pushed by populists in recent years is the "QAnon" theory. According to it, as Mark Scott writes, President Trump is battling a plot devised by global elites and paedophile networks. ${ }^{80}$ It has its source in anonymous entries on the "4Chan" portal, posted by an alleged high-level U.S. government official. It seems that the purpose of its dissemination is to secure support for itself in a radically inclined part of American society, which is more prone to conspiratorial view of the world. Trump himself, however, claimed that he doesn't know much about the movement, and when asked at a press conference in the White House whether he, according to the theory, is secretly saving the world from this satanic cult of paedophiles and cannibals, his reply was that, even if he is, then is that supposed to be a bad thing or a good thing? ${ }^{81} \mathrm{He}$ added that he actually wanted to save the world from the philosophy of the radical left. According to Scott, 'QAnon' also found supporters among Italian anti-vaccineists. From the research point of view, it is interesting in that it combines various, minor conspiracy theories, such as those related to the Kennedy family. It uses a Manichean dialectic, according to which the evil side is demonic enough to resort to satanic ritual murder, which is a reference to conspiracy theories about the New World Order and Freemasonry.

The world of medicine, like the world of politics, is exposed to the presence of conspiratorial thinking. ${ }^{82}$ Studies show that belief in political conspiracies manifests

77 L. Zdybel, Idea spisku i teorie spiskowe w świetle analiz krytycznych i badań historycznych, Lublin 2002, p. 26.

78 Ibid., p. 69.

79 M. Grzesiak-Feldman, Psychologia myślenia spiskowego, Warszawa 2016, p. 43.

80 M. Scott, QAnon, wielka amerykańska teoria spiskowa, zyskuje setki tysięcy zwolenników w Europie, 26 October 2020, at <https://wiadomosci.onet.pl/politico/teorie-spiskowe-qanon-zyskuje-setkitysiecy-zwolennikow-w-europie/kcwdxj7>, 17 November 2020.

81 QAnon: Trump lauds bizarre conspiracy theory, 20 August 2020, at <https://www.bbc.com/news/av/ world-us-canada-53844108>, 17 November 2020.

82 G. Andrade, "Medical Conspiracy Theories: Cognitive Science and Implications for Ethics", Medicine, Health Care and Philosophy, no. 23 (2020), p. 505. 
a strong correlation with belief in medical conspiracy theories. ${ }^{83}$ The metatheory of conspiracy in alternative medicine, the theory of Big Pharma, points to a conspiracy of pharmaceutical companies, regulators, politicians and others working in collusion against the public interest ${ }^{84}$ which, from the perspective of alternative medicine specialists, proves once again that, in the field of medicine, not only the medical elite, but the elites in a broader sense are involved in that conspiracy. A study by N. Galliford and A. Furnham indicated that belief in medical conspiracies is associated with low self-esteem, low scrupulousness, right-wing political views, younger age, and greater faith in the benefits of alternative medicine. ${ }^{85}$ Interestingly, according to this study, university graduates were more likely to have the potential to believe in medical conspiracy theories. Detailed studies of attitudes reveal new perspectives and suggestions of research directions in alternative medicine as a social and political phenomenon. A 2013 American public opinion poll indicated that $37 \%$ of the respondents agreed with, and $31 \%$ were neutral to the conspiracy theory that government agencies, under pressure from the pharmaceutical industry, concealed cures for cancer and other diseases from the public. ${ }^{86}$ Only $32 \%$, that is, a minority, did not share this view. As shown by the CBOS research report, in Poland the population believing that vaccinations are promoted not because they are really needed, but because they are in the interest of pharmaceutical companies constitutes about $22 \%$ of respondents. ${ }^{87}$ The research by Daniel Jolley and Karen Douglas demonstrates that people who believe in the conspiracy theories about harmful side effects of vaccines are more likely not to vaccinate their children than those who do not believe in them. ${ }^{88}$ Another research carried out by CBOS found that those who read content containing conspiracy theories about immunization were opposing the idea of having their own children immunized to a larger extent. Of course, we should keep in mind that these studies were experimental. The obtained result is related to the feeling of disappointment, helplessness and distrust towards authorities, ${ }^{89}$ which indicates a close relationship between anti-elitism and conspiratorial thinking mentioned earlier in this paper.

Vaccine conspiracy theories are such an influential segment of alternative medicine that they have been recognized by the World Health Organization (WHO) as one of the top ten threats to humanity in $2019.9^{90}$ The authors of the list point out that this

83 N. Galliford, A. Furnham, "Individual Difference Factors and Beliefs in Medical and Political Conspiracy Theories”, Scandinavian Journal of Psychology, vol. 58, no. 5 (2017), pp. 422-428, p. 2.

84 R. Blaskiewicz, “The Big Pharma Conspiracy Theory”, Medical Writing, vol. 22, no. 4 (2013), p. 258.

85 N. Galliford, A. Furnham, "Individual Difference..., pp. 423-424.

86 J.E. Oliver, T. Wood, "Medical Conspiracy Theories and Health Behaviors in the United States", JAMA Internal Medicine, vol. 174, no. 5 (2014), p. 817.

87 "Stosunek do szczepień ochronnych dzieci. Komunikat z badań", Centrum Badania Opinii Spotecznej, no. 9 (2019), at <https://cbos.pl/SPISKOM.POL/2019/K_009_19.PDF>, p. 22, 9 November 2020.

88 Ibid., p. 48.

89 Ibid.

90 Ten Threats to Global Health in 2019, at <www.who.int/emergencies/ten-threats-to-global-healthin-2019>, 5 May 2019. 
form of disease prevention is one of the methods that, due to their low cost, are extremely effective. The promotion of such theories leads to a decrease in vaccination coverage, and, consequently, to an increase in the incidence of infections. ${ }^{91}$ The former physician Andrew Wakefield can be considered the founding father of the modern anti-vaccine movement. He is the co-author of the famous study on the relationship between the MMR vaccine and autism, which, on the one hand, was criticized for its low-quality methodology (a study on a sample of 12 people), and on the other, for the falsification of data, as revealed in the course of a journalistic investigation. ${ }^{92}$ Allegedly, pharmaceutical companies were hiding from the public the truth about the safety of the preparations they produced. Gabriel Andrade notes that since the invention of the measles vaccine by Edward Jenner (1798), there have been numerous conspiracy theories questioning the validity of vaccination. ${ }^{93}$ At the time, the public was convinced that they had such side effects as horns growing out of the vaccinated people's heads. Today, the side effects are described in detail on product leaflets, but according to alternative medics, these data are being manipulated. Conspiracy narratives today are definitely more intricate and sophisticated. As Agnieszka Kańska notes, Conspiracy theories about the alleged threat posed by vaccines assume the implicit assumption that all doctors, nurses, pharmacists, rank and file vaccine lab employees, individual state drug safety authorities and the WHO are involved in a procedure that leads to the death and disability of thousands of people. ${ }^{94}$ Therefore, it is not even a classic conspiracy theory in which the 'Evil' is a small group of influential people; alternative medicine goes further here and extends the Other to the entire elite, but also to the rank and file employees of various institutions.

In Poland, the best known anti-vaccination organization is the Ogólnopolskie Stowarzyszenie Wiedzy o Szczepieniach STOP NOP ('Stop the Adverse Vaccine Reaction National Vaccine Knowledge Association'), which treats Wakefield as an authority. It is popular not only thanks to its presence in social media, ${ }^{95}$ but also because of organizing rallies against obligatory vaccinations or by proposing civic initiative drafts of laws, so far rejected by the Polish Parliament. ${ }^{96}$ The description of the activities of

91 Ibid.

92 T.S. Sathyanarayana Rao, C. Andrade, The MMR Vaccine and Autism: Sensation, Refutation, Retraction, and Fraud, at <www.ncbi.nlm.nih.gov/pmc/articles/PMC3136032/>, 5 May 2019; Artykut Wakefielda wiązacy szczepionkę MMR z autyzmem byt oszustwem, 14 April 2011, at <www.mp.pl/ pacjent/szczepienia/sytuacje-szczegolne/59132, artykul-wakefielda-wiazacy-szczepionke-mmr-zautyzmem-byl-oszustwem>, 5 May 2019.

93 G. Andrade, “Medical Conspiracy Theories..., p. 506.

94 A. Kańska, Teorie spiskowe jako populistyczne narzędzie w represji grup marginalizowanych, 7 November 2020 .

95 Profile "Ogólnopolskie Stowarzyszenie Wiedzy o Szczepieniach STOP NOP”, at <www.facebook. com/stowarzyszeniestopnop/>, 5 May 2019.

96 J. Ćwiek, "Projekt ustawy stowarzyszenia STOP NOP dot. szczepień trafil do Sejmu", Rzeczpospolita, 1 August 2018, at <https://www.rp.pl/Zdrowie/308019957-Projekt-ustawy-stowarzyszenia-STOPNOP-dot-szczepien-trafil-do-Sejmu.html>, 8 November 2020. 
'STOP NOP' is a specific ideological basis for all activities of the organization: our goal is to provide comprehensive information about vaccinations, especially about the risk associated with them and the freedom of choice enjoyed by parents from 20 European countries. We are not an anti-vaccine movement, we are a pro-patient movement. 'STOP NOP' is therefore committed to standing by "ordinary people" and, in a conservative manner, refers to the family as the basic social unit. Thus, this narrative admits that the goal of the organization is, first of all, to achieve an applicable legislation in which there is no obligation to vaccinate. In addition, it directly accuses government institutions, together with pharmaceutical companies, of concealing the side effects associated with vaccinations. 'STOP NOP' tries to rebuff the main allegation against the organization, arguing that they are really acting for the benefit of patients and are not opposed to vaccines at all. Critical analysis calls to question this narrative and to ask the following question: if the association argues that it is not "anti-vaccine" at all, why is it publishing so much critical material on vaccines as medical remedy? If it is opposed not to vaccinations alone, but only to legal coercion, then why, instead of supporting its position with philosophical or ethical arguments, it criticises the vaccines, presenting them in its narrative as harmful? The methodological flaw of alternative medicine is fully revealed here, which is convenient to it, because it allows the logic of the argument to be partially suspended. However, it does not seem to have any significance in the face of emotionally marked narratives, as well as constructed impulsive identities.

Justyna Socha, the head of 'STOP NOP', works as a journalist for a far-right "Warszawska Gazeta" paper ${ }^{97}$ and has run for the Polish Parliament in the past. During the 'STOP NOP' protest in 2018, one of the speakers was the right-wing columnist, film director and Konfederacja ('Confederation') politician Grzegorz Braun, a former candidate for the president of the Republic of Poland and, since 2019, a member of the Polish Parliament, who compared the fight against compulsory vaccination to defending Latin civilization. ${ }^{98}$ Today, both Socha and the vice-president of 'STOP NOP' work as social assistants for Braun, who is a member of the Parliamentary Group for the Safety of Vaccinations for Children and Adults. Grzegorz Braun has repeatedly appeared at street protests organized by the association in question. In his parliamentary speech of January 22, 2020, he said about the draft amendment to the Act on the State Sanitary Inspection (Sanepid) that the Inspection's data on the falling immunization rates among children are produced out of thin air, as they do not take into account the implementation of these vaccinations at a different place and time. ${ }^{99}$ Braun's opposition to the restriction of vaccination regulations was motivated by his attachment to the traditional principle of subsidiarity... ${ }^{100}$ Medical conspiracy theories and populist politics also mix at a higher level. Donald Trump has

7 Feuilletons of Justyna Socha, at <www.warszawskagazeta.pl/justyna-socha>, 5 May 2019.

98 Grzegorz Braun, Hubert Czerniak i Arkadiusz Tetela na proteście STOP NOP, at <www.youtube.com/ watch?v=jaPEPNSaSpw>, 5 May 2019.

99 Speeches delivered during parliamentary sessions, Session 4 on 22 January 2020 (day 1), G. Braun, at <http://search.sejm.gov.pl/SejmSearch/ADDL.aspx?SelectResult>, 8 November 2020.

100 Ibid. 
invited Robert Kennedy Jr. (son of Robert Kennedy, former US attorney general), known for his anti-vaccine beliefs, to join his administration. Trump himself was supposed to be sceptical about anti-vaccine theories, but as he argued, he himself knew a case of autism caused by vaccination. ${ }^{101}$ Conspiracy theories of alternative medicine can therefore be a component of the narrative of political populists. Conversely, alternative medics may aspire to political positions based on their alternative-medical activities, such as Hubert Czerniak, who ran for the Parliament from the list of Kukiz '15 in 2015, currently suspended to practice medicine as a medical doctor. ${ }^{102}$

\section{JERZY ZIĘBA AS A MEDICAL POPULIST. A CASE STUDY}

Alternative medicine practitioners present their identity narratives in all their abundance, justifying them in detail in long films or in books. This allows building a trusted group of followers, exposed to long-term narrative influence. The response of the recipients and the analysis of the content make it possible to examine how these narratives are absorbed, and therefore how strongly they influence the identity they express in views on medicine, politics and society. For this purpose, the author examined the anti-vaccination narratives of Jerzy Zięba, the most popular Polish alternative medicine practitioner of the 2010s, who combines anti-elitism, conspiracy theories and strong references to group identity in his messages. He can pride himself on being popular not only on the Internet, where his Facebook profile ${ }^{103}$ has 352,000 followers. He is primarily a public speaker and author of the best-selling book ${ }^{104}$ Ukryte terapie (Hidden Therapies). ${ }^{105}$ In one of his recordings, Jerzy Zięba admitted producing his dietary supplements under the Visanto brand, ${ }^{106}$ which he was said to have done at the request of his supporters. ${ }^{107}$ Zięba therefore combines alternative medicine with business. He is a celebrity both in the Internet and in traditional media, and a model of political populism. Zięba appeared in such programs as 'Uwaga!' (TVN), ${ }^{108}$ 'Dzień dobry

101 Vaccine Skeptic Robert Kennedy Jr. Asked to Head Trump 'Vaccination Safety' Committee, at <https:// www.medicinenet.com/script/main/art.asp?articlekey=200826>, 8 November 2020.

102 J. Kowalik, Kiszona kapusta za 95 zt, leczenie raka witamina B17, naenergetyzowana woda. Poczet polskich znachorów, 30 March 2019, at <https://www.newsweek.pl/polska/hubert-czerniak-jerzyjaskowski-zbigniew-nowak-tadeusz-ceglinski-jerzy-zieba/kmrztbp>, 8 November 2020.

103 Profile "Ukryte terapie - Jerzy Zięba", at <www.facebook.com/ukryteterapie/>, 26 June 2019.

104 See R. Badowski, Twierdzi, że woda ma pamięć i święci triumfy w Empiku. Oto, czym zaczytują się Pola$c y$, at <innpoland.pl/134111,ta-ksiazka-znanego-uzdrowiciela-robi-furore-wsrod-polakow-trafila-naliste-bestsellerow-empiku>, 26 June 2019.

105 J. Zięba, Ukryte terapie..., part 1; J. Zięba, Ukryte terapie. Czego ci lekarz nie powie, part 2, Rzeszów 2016.

106 Jerzy Zięba o marce VISANTO, at <www.youtube.com/watch?v=VMYvqfnhq80>, 26 June 2019.

107 Ibid.

108 Jerzy Zięba i jego ukryte terapie. Kulisy stawy, at <uwaga.tvn.pl/reportaze,2671,n/jerzy-zieba-i-jego-ukryte-terapie-kulisy-slawy,218161.html>, 26 June 2019. 
TVN',109 'Skandalista' (Polsat), ${ }^{110}$ which were devoted entirely to him and through which he promoted his health narratives, although in every instance facing a criticism of journalists. The highly popular Radio Katowice broadcast 'Alfabet Jerzego Zięby'111 ('Alphabet of Jerzy Zięba'), which he co-hosted with Jarosław Krajewski, was devoted to various medical issues, including sepsis, ${ }^{112}$ and medical experiments. ${ }^{113}$ The show was cancelled due to complaints filed to the management of the radio and the Krajowa Rada Radiofonii i Telewizji (National Broadcasting Council). As reported by 'Wirtualne Media, The National Broadcasting Council stated that in its opinion the program could promote behaviours detrimental to the health of its audience. ${ }^{114}$ Zięba was a regular guest of Piotr Barełkowski on the right-wing Internet television "wPolsce," in which he also has his own show entitled 'Czego ci lekarz nie powie?' ('What your doctor will never tell you'), in the format of an extended interview. Professor Cezary Szczylik of Klinika Onkologii Centralnego Szpitala Klinicznego WAM (Oncology Center of the Central Clinical Hospital, the Military Institute of Medicine) is critical of Zięba's views, calling it cosmic nonsense. ${ }^{115}$ Paweł Jarosz, a medical doctor and blogger, called Zięba a charlatan, listing the abuses of science committed by him. ${ }^{116}$ The series of articles about Jerzy Zięba was written by biologist and blogger Łukasz Sakowski for "Newsweek". In one of the published articles, he quoted his conversations with people harmed as a result of health advice offered by Jerzy Zięba. ${ }^{117}$

Zięba emphasizes his many years of experience, which suggests having appropriate theoretical and practical knowledge, thanks to which he can be considered an expert and even an authority. ${ }^{118}$ By calling himself a certified clinical bypnotherapist, he creates the image of someone with necessary knowledge and skills certified by documents. It is also worth noting that the areas of "specializations" indicated by Zięba include chronic

109 Naturoterapia. Znachorstwo czy alternatywna metodaleczenia?, at < dziendobry.tvn.pl/a/naturoterapia-znachorstwo-czy-alternatywna-metoda-leczenia>, 26 June 2019.

110 Skandaliści - Jerzy Zięba, at <www.polsatnews.pl/wideo-program/skandalisci-jerzy-zieba_6677102/>, 26 June 2019.

111 See a compilation of all episodes "Alfabet Jerzego Zięby" posted by one of the users, at <www.youtube. com/watch?v=AoWWqp5NGiQ>, 26 June 2019.

112 At <www.youtube.com/watch?v=hO-5Asqz4oo>, 26 June 2019.

113 At <www.youtube.com/watch?v=_vzWmz9kx8Q>, 26 June 2019.

114 N. Bochyńska, Radio Katowice zdjęto $z$ anteny audycje 'Alfabet Jerzego Zięby' o niekonwencjonalnych metodach leczenia, at <www.wirtualnemedia.pl/artykul/radio-katowice-zdjelo-z-anteny-audycje-alfa bet-jerzego-zieby-o-niekonwencjonalnych-metodach-leczenia>, 26 June 2019.

115 Reportage "Uwaga TVN" about Jerzy Zięba, at < uwaga.tvn.pl/reportaze,2671,n/jerzy-zieba-i-jego-ukryte-terapie-kulisy-slawy,218161.html>, 26 June 2019.

116 P. Jarosz, Ukryte terapie czy ukryte ściemy - czyli jak szarlatani zarabiają miliony, 9 January 2017, at $<$ www.niezdrowybiznes.pl/ukryte-terapie-ukryte-sciemy-czyli-szarlatani-zarabiaja-miliony>, 26 June 2019.

117 Ł. Sakowski, 'Ten cztowiek szkodzi ludziom. Mówią ofiary Jerzego Zięby, at <www.newsweek.pl/polska/spoleczenstwo/ofiary-jerzego-zieby-opowiadaja-pod-nazwiskami-o-jego-terapiach/hzb8y62>, 26 June 2019.

118 Jerzy Zięba’s website, at <www.jerzyzieba.com>, 26 June 2019. 
diseases and cancer, which are not merely onerous and painful, ${ }^{119}$ but, when left untreated, terminal. The target group chosen by Jerzy Zięba consists of often desperate people, abandoned by conventional medicine, deemed incurable (chronic diseases) or terminally ill (cancers that are incurable by conventional medicine). For this reason, it is an excellent target, particularly susceptible to alternative medicine claims. Like political populists, alternative practitioners target in their narratives those who feel exclud$\mathrm{ed}^{120}$ from genuine social life and deprived of any hope for improving their fate.

\subsection{An Analysis of Zięba's Narration on Vaccines}

In order to understand how Jerzy Zięba builds a populist identity, it is necessary to analyse his narrative regarding immunization. It is important because Zięba, as a celebrity and a health guardian, discourages both his audiences and potentially interested outsiders from vaccinating themselves and their own children. Certainly, he does not directly advocates taking, or rather refraining from this type of action, which, obviously, is a smart way to avoid any potential consequences. Due to the fact that Zięba's highcirculation books are important sources of his narrative, the author decided to examine the narrative regarding vaccinations, which can be found in the second part of the bestseller Hidden Therapies in the chapter Vaccines - a Great Deception.

Jerzy Zięba's narrative about vaccinations begins with an information that he possesses knowledge about vaccinations which he wishes to disclose and that it should be disclosed in this part [of Hidden Therapies]. Right now. ${ }^{121} \mathrm{He}$ goes on to say that parents are told to make decisions about vaccinating their children, and some things are unlikely to be made public, so that parents can make decisions without having access to the information they need to make a good decision. Zięba rhetorically asks are we not dealing here with a fraud on a huge scale?, because, in his opinion, vaccinations are not medicines, because medications are used to heal. ${ }^{122}$ Zięba believes that the reason for such farfetched regulations is the state's actions in the interests of pharmaceutical companies that can count on a steady profit thanks to applying drug reimbursement system to vaccines. He introduces here the conspiracy theory about Big Pharma as actually controlling the course of public and political affairs. Zięba argues that when it comes to vaccinations, there are no real studies ${ }^{123}$ confirming their effectiveness, although they are classified as drugs, which, according to Zięba, should require being tested for many years. Therefore, the elite conspiracy has the aspect of falsifying social reality. It is interesting that Jerzy

119 The World Health Organization draws attention to the fact that health is not merely the absence of illness but a complete state of physical, psychological and social well-being. See Constitution of The World Health Organisation, October 2006, at <www.who.int/governance/eb/who_constitution_en.pdf>, 26 June 2019.

120 J. Pakulski, "Ruchy populistyczne i degeneracja elit przywódczych - analiza weberowska”, Zoon Politikon, no. 7 (2016), p. 59.

121 Jerzy Zięba, Ukryte terapie..., part 2, p. 301.

122 Ibid.

123 Ibid., p. 304. 
Zięba postulates that this research should be carried out on a double-blind sample of thousands of children, which stresses his commitment to scientific reliability. Vaccinations are cocktails (toxic, therefore harmful), and the society (especially parents) are not aware, due to the lack of research, of the real risk of vaccination. Neither the officials nor the vaccinating doctors take any responsibility, as they are protected by Polish legal system. ${ }^{124} \mathrm{He}$ explicitly calls vaccinations substances promoting the development of cancer. ${ }^{125}$ Zięba cites the alleged experience of a certain Dr Andrew Moulden, who said that each vaccination causes microtrauma to the brain. He "proved" this by photographing $5,000,000$ faces of children who were supposed to have post-vaccination lesions. On the one hand, Zięba declares its adherence to medical standards set by the medical elite, and on the other hand he denies them, rejecting the aspect of their clinical practice.

According to Zięba, it is a disaster for us, Poles, by which he introduces the nation to the alternative-medical identity as an exterminated entity. ${ }^{126} \mathrm{He}$ claims that vaccines are political, and if the true number of cases of vaccine complications were revealed, no politician would make the decision to vaccinate Polish children. ${ }^{127}$ In the end of his narrative on vaccines, he claims that doctors have been deceived, including our Polish ones too. The conspiracy of pharmaceutical companies is therefore not only global, but also domestic. The medical community is extremely corrupted. Jerzy Zięba claims that in his message about vaccinations he cares about the health of Poles; and the authorities, by ignoring his publication, turn out to be unable to defend the health and lives of Poles. Polish parents and Polish society are not informed about anything, Poles expect to be told the truth. Poles will not hear the truth from journalists who are in the pocket of the pharmaceutical industry (and according to Zięba, they never tell the truth). Jerzy Zięba recalls his meetings with Poles both in Poland or abroad. He regrets that facts are not communicated to Polish society. In the populist conclusion of the narrative, Jerzy Zięba states that he would support vaccinations if they were as safe as they are not. ${ }^{128}$

Summarizing the analysis of the vaccine narrative contained in Hidden Therapies, and interpreting it in terms of conspiratorial thinking, it is worth noting that its apparent internal logical structure obscures the need to support it with rhetorical tricks, even a certain narrative complexity, casually referring to research and doing it in an instrumental and arbitrary manner, introducing an emotional bias into the message and directing it at those parents who have doubts. A trait characteristic of Zięba is his populist message, referring to the figure of a Pole opposed to the Others - the international pharmaceutical industry and scientists who plot against the community. Thus, the dispute between alternative medicine and conventional medicine has an ethnic and national shade, and the identity of a Pole is added to the identity of a patient who is a victim of medical institutions.

124 Ibid., p. 307.

125 Ibid.

126 Ibid., p. 312.

127 Ibid.

128 Ibid., p. 322. 


\subsection{Reproduction of Narratives}

In order to investigate how Jerzy Zięba's narratives are being assimilated and repeated (reproduced) and validated by his followers, the author analysed 50 comments under the most popular video materials showing up in 'Jerzy Zięba' search results on YouTube. Of course, only those materials ${ }^{129}$ that could be commented on were considered. Polemic comments (coming almost exclusively from those sceptical of Jerzy Zięba's views) as well as the usual greetings and thanks were omitted. They were analysed in terms of content, examining which phrases are common to them and interpreting their content. ${ }^{130}$

In the comments of his supporters, Jerzy Zięba is called, inter alia, sensational, wise, a genuine doctor, Doctor Zięba, Professor Zięba, an amazing person, a wonderful man, a Pole and a patriot, one of very few specialists in his field, an amazing authority, or even as one of the followers wrote - Prometheus. This shows the astounding respect that Zięba enjoys. He is not a doctor or a scientist at all, although thus called by his supporters, which confirms the view of Izabela Cendal that even in the face of the collapse of medical authorities, society still needs a strong authority that will lead people through the intricate paths of medicine ${ }^{131}$ It is worth paying attention to the simple reproductions of Jerzy Zięba's narratives. Internet users are convinced that doctors do not want to be up to date with the topics that Zięba talks about, and as one of his supporters echoes him, doctors are freaks. They are mindless machines playing only programmes installed in them during their studies. Doctors and modern medicine are only useful in emergencies, but the rest should be avoided (this is a simple replication of Zięba's narrative that medicine works only in life-saving cases and not in complex diseases). Another internet user explains that the aforementioned pharmacology is a buge, probably the largest business in the world, and Jerzy Zięba is the one who is not afraid to face pharmacists and who is annoying to certain groups. Another follower explains that many people get sick, and a handful of pharmaceutical companies make money on the pain and suffering of children. Every doctor should be as universal as Jerzy [Zięba], unfortunately, doctors serve pharmacology blindly. Comments such as for global pharmaceutical companies, a person is only an item on a list, and his or her death is irrelevant allow us to understand that in the eyes of Jerzy Zięba's supporters we live in a time of dictatorship, in which individuals do not

129 The comments for the analysis come from the videos: JAK POZBYĆ SIE MIAŻDŻYCY Jerzy Zię$b a$, at <www.youtube.com/watch?v=3CA8pJ11rxQ>; Ukryte terapie, cz. 1 - Jerzy Zięba - 15 July 2014, at <www.youtube.com/watch?v=4fhezw-8_pM>; Ukryte Terapie, cz. 5 - Cukier - Jerzy Zięba - 30 September 2014, at <www.youtube.com/watch?v=leVEDIvjLUo>; JERZY ZIĘBA - ZAKWASZENIE ŻOEADKA, at <www.youtube.com/watch?v=1 hunhblv9HA>; Ukryte terapie, cz. 2 Jerzy Zięba - 22 July 2014, at <www.youtube.com/watch?v=9J90IVw3vqE>, 22 June 2019.

130 For better readability of Internet users' statements, italics were used. The analysis was conducted in June 2019.

131 I. Cendal, Od Hahnemanna do Zięby. Wptyw autorytetu na postrzeganie medycyny - homeopatia, efekt placebo, propaganda antyszczepionkowa, at <https://depot.ceon.pl/bitstream/handle/123456789/ 13487/Wp\%C5\%82yw_autorytetu\%20_na\%20_postrzeganie\%20_medycyny.pdf?sequence=1\& isAllowed=y>, p. 101, 22 June 2019. 
matter and have no rights, are ultimately helpless in the face of the pharmaceutical industry, state authorities, health services and science. The system does not allow them to articulate their views. Yet another Internet user sees all this as a massive crusade against this man (Jerzy Zięba), although he probably has a broader perspective, not only about the plotting pharmaceutical industry, but also the bureaucratic apparatus of the state. An important aspect of Zięba's narrative, repeated by his supporters, is that of a conspiracy against naturopaths (such as Jerzy Zięba): In the United States, "complementary doctors," such as Mr Zięba, do not hide, but they are persecuted and some even die in unexplained circumstances. Another entry also addresses the issue of alleged murders in alternative medicine practices: Naturopathic physicians are also persecuted here [in the US], and even killed or imprisoned. Disobedient alternative medicine practitioners operating within the field of conventional medicine are thus secretly exterminated in this Manichean clash, just as President John F. Kennedy was killed in 1963 by a secret world government, allegedly revealing the truth about the Illuminati rule. It should be noted how willingly the conspiracy narratives are repeated in the comments of Zięba's supporters, constituting - as it turns out in the course of the analysis - their second most important element after praising Zięba. In addition to these "voiced" narratives, there are also narratives that legitimize health recommendations on the dangers of drugs that are destructive to the body or associated in an unexplained way with diseases, pills that are stuffed, dairy products (it is worth considering if yoghurt or cheese are a bealthy choice) or sugar (filling a wide range of different products). One can treat health problems, as Zięba says, in a simple, natural way - everything has its cause and effect. Individuals have enough internal power of their own organisms to heal themselves, as long as they do not poison themselves. To this end, a proper diet is necessary (food is our medicine). Modern medicine treats each organ separately, and ignores the need for a holistic approach, therefore, in the opinion of Zięba and other alternative medicine practitioners, it rejects biomedicine and holistic medicine.

\section{CONCLUSIONS}

Comparative studies of political populism and alternative medicine undertaken by the author tried to show these two phenomena as analogous in terms of their approach to elites, conspiratorial thinking and strong sense of belonging to a group. The aim of the dialectical approach was to emphasize that inasmuch as political populism is necessary for liberal democracy, because it reflects the voice of the middle-class and lower-class citizens, indicates that some of its mechanisms are defective, conventional medicine needs alternative medicine because it provides a safety valve for disappointment with science and hope for the patients in situations where scientific medicine is unable to help (civilization diseases, neoplastic diseases) and only offers symptomatic or palliative treatment. Following Maciej Gdula's approach to neoliberalism and Kamil Minkner's approach to the political nature of conspiracy theories, one can put forward the argument that alternative medicine only fights the effects of mainstream treatments, and 
not the genuine causes of conventional medicine's flaws, so it is impossible to permanently reform the situation with such an approach. Such a heterogeneous and ineffective social movement is convenient to the authorities and scientific and research institutions, because it concentrates social energy which is potentially pushing for reforms, but gives it a direction that allows medicine to maintain the status quo. Therefore, alternative medicine practitioners and their followers resort to building a consolidated movement fighting for change in relatively closed communities that, gathered around specific alternative medicine practitioners or alternative media producing their own narratives, provide them with identity - in the dialectical approach employed by the author of the false identity. In the discourses of alternative medicine, there is very little in-depth critique of today's (post) industrial civilization that produces patients en masse, as well as the reasons why it is being treated in this particular manner, and not in a different one. It would be necessary in subsequent and more in-depth studies to adopt a radically critical approach, capable of moving beyond the horizon set by the dialectical relationship of conventional medicine and alternative medicine. It is particularly important that during the SARS-CoV-2 pandemic there has been a boom of populist narratives - both political and medical, which will be of great importance in the postpandemic world.

\section{BIBLIOGRAPHY}

Andrade G., "Medical Conspiracy Theories: Cognitive Science and Implications for Ethics", Medicine, Health Care and Philosophy, no. 23 (2020), https://doi.org/10.1007/ s11019-020-09951-6.

Artykut Wakefielda wiążacy szczepionkę MMR z autyzmem byt oszustwem, 14 April 2011, at <www.mp.pl/pacjent/szczepienia/sytuacje-szczegolne/59132,artykul-wakefielda-wiazacyszczepionke-mmr-zautyzmem-byl-oszustwem >.

Badowski R., Twierdzi, że woda ma pamięći święci triumfy w Empiku. Oto, czym zaczytują się Polacy, at <innpoland.pl/134111,ta-ksiazka-znanego-uzdrowiciela-robi-furore-wsrod-polakow-trafila-na-liste-bestsellerow-empiku>.

Baszczak B., "Tożsamość człowieka a pojęcie narracji”, Analiza i Egzystencja, no. 14 (2011).

Blaskiewicz R., "The Big Pharma Conspiracy Theory”, Medical Writing, vol. 22, no. 4 (2013), https://doi.org/10.1179/2047480613Z.000000000142.

Blaxter M., Zdrowie, Warszawa 2009.

Bochyńska N., Radio Katowice zdjęto $z$ anteny audycje 'Alfabet Jerzego Zięby' o niekonwencjonalnych metodach leczenia, at <www.wirtualnemedia.pl/artykul/radio-katowice-zdjelo-z-ante ny-audycje-alfabet-jerzego-zieby-o-niekonwencjonalnych-metodach-leczenia> .

Bogusz A., "Relacje między pacjentem a lekarzem", in B. Płonka-Syroka (ed.), Cztowiek natura, kultura - studia z historii i antropologii medycyny i farmacji spotecznej, Wrocław 2009.

Bourdieu P., "Homo academicus", Praktyka Teoretyczna, vol. 7, no. 1 (2013), at <http://www. praktykateoretyczna.pl/PT_nr7_2013_NOU/03.Bourdieu.pdf $>$.

Branicki W., Tożsamość a wirtualność, Kraków 2009. 
Brzeziński T., "Naturalne i niekonwencjonalne metody leczenia”, in Idem (ed.), Historia medycyny, Warszawa 1995.

Burke P., Spoteczna historia wiedzy, Warszawa 2016.

Castanho Silva B., Vegetti F., Littvay L., "The Elite Is Up to Something: Exploring the Relation Between Populism and Belief in Conspiracy Theories", Swiss Political Science Review, vol. 23, no. 4 (2017), https://doi.org/10.1111/spsr.12270.

Cendal I., Od Hahnemanna do Zięby. Wptyw autorytetu na postrzeganie medycyny - homeopatia, efekt placebo, propaganda antyszczepionkowa, at <https://depot.ceon.pl/bitstream/han dle/123456789/13487/Wp\%C5\%82yw_autorytetu\%20_na\%20_postrzeganie\%20_me dycyny.pdf ? sequence $=1$ \&isAllowed $=y>$.

Cleen B. de, "The Party of the People Versus the Cultural Elite: Populism and Nationalism in Flemish Radical Right Rhetoric about Artists", JOMEC Journal, no. 9.

Constitution of The World Health Organisation, October 2006, at <www.who.int/governance/ eb/who_constitution_en.pdf $>$.

Ćwiek J., "Projekt ustawy stowarzyszenia STOP NOP dot. szczepień trafił do Sejmu”, Rzeczpospolita, 1 August 2018, at <https://www.rp.pl/Zdrowie/308019957-Projekt-ustawy-sto warzyszenia-STOP-NOP-dot-szczepien-trafil-do-Sejmu.html>.

Duffy T.P., "The Flexner Report - 100 Years Later", Yale Journal of Biology and Medicine, vol. 84, no. 3 (2011), at <https://www.ncbi.nlm.nih.gov/pmc/articles/PMC3178858/>.

Eatwell R., Goodwin M., Narodowy populizm. Zamach na liberalna demokracje, Katowice 2020.

Engel G., "The Need for a New Medical Model: A Challenge for Biomedicine”, Science, vol. 196, no. 4286 (1977), https://doi.org/10.1126/science.847460.

Etyczne aspekty upowszechniania poglądów nienaukowych, Komitet Etyki w Nauce Polskiej Akademii Nauk, Stanowisko 1/2020 z dnia 24 lutego 2020 r., 18 May 2020.

Feuilletons of Justyna Socha, at <www.warszawskagazeta.pl/justyna-socha> .

Foster A., Ukip leader Nigel Farage's most memorable speeches including his FAREWELL today, 16 September 2016, at <https://www.express.co.uk/news/politics/686024/Ukip-leaderNigel-Farage-speeches-resignation-European-Parliament-Brexit-victory $>$.

Galliford N., Furnham A., "Individual Difference Factors and Beliefs in Medical and Political Conspiracy Theories", Scandinavian Journal of Psychology, vol. 58, no. 5 (2017), https://doi. org/10.1111/sjop.12382.

Gdula M., Nowy autorytaryzm, Warszawa 2018.

Giddens A., Nowoczesność i tożsamość, Warszawa 2006.

Griffin E., Podstawy komunikacji spotecznej, Gdańsk 2003.

Grzegorz Braun, Hubert Czerniak i Arkadiusz Tetela na proteście STOP NOP, at <www.youtube. $\mathrm{com} /$ watch?v=jaPEPNSaSpw $>$.

Grzelak K., Porównat szczepienia do ludobójstwa. Surowy wyrok dla lekarza z Eodzi, 25 May 2020, at <https://www.focus.pl/artykul/porownal-szczepienia-do-ludobojstwa-surowywyrok-dla-lekarza-z-lodzi>.

Grzesiak-Feldman M., Psychologia myślenia spiskowego, Warszawa 2016, https://doi.org/10. 31338/uw.9788323522157.

Hendrickson D., Zollinger B., McCleary R., "Determinants of the Use of Four Categories of 
Complementary and Alternative Medicine", Complementary health practice review, vol. 11, no. 1 (2006), pp. 3-26, https://doi.org/10.1177/1533210106288080.

Hofstadter R., The Paranoid Style in American Politics and Other Essays, New York 1965.

Jak Rockefellerowie zatożyli big pharme i zniszczyli medycyne naturalna, at < https://www.odkry wamyzakryte.com/rockefellerowie-zniszczyli-medycyne-naturalna/ > .

Jarosz P., Ukryte terapie czy ukryte ściemy - czyli jak szarlatani zarabiaja miliony, 9 January 2017, at <www.niezdrowybiznes.pl/ukryte-terapie-ukryte-sciemy-czyli-szarlatani-zarabiaja-miliony>.

Jaśkowski J., "Medycyna Rockefllerowska, czyli medycyna sądownie udowodniona”, Polish Club, at <https://www.polishclub.org/2018/09/27/medycyna-rockefellerowska-czylimedycyna-sadownie-udowodniona/ $>$.

Jerzy Zięba i jego ukryte terapie. Kulisy stawy, at <uwaga.tvn.pl/reportaze,2671,n/jerzy-zieba-ijego-ukryte-terapie-kulisy-slawy,218161.html $>$.

Jerzy Zięba o marce VISANTO, at <www.youtube.com/watch?v=VMYvqfnhq80>.

"Kaczyński: W Polsce obok elity postkomunizmu jest już nowa elita, która jest w stanie zmieniać Polskę", Gazeta Prawna, 14 September 2019, at <https://www.gazetaprawna.pl/ artykuly/1430132,kaczynski-w-polsce-obok-elity-postkomunizmu-jest-juz-nowa-elita-kto ra-jest-w-stanie-zmieniac-polske.html>.

Kańska A., "Teorie spiskowe jako populistyczne narzędzie w represji grup marginalizowanych”, Studenckie Prace Prawnicze, Administratywistyczne i Ekonomiczne, vol. 31 (2020), pp. 6792, https://doi.org/10.19195/1733-5779.31.5.

Kowalik J., Kiszona kapusta za 95 zt, leczenie raka witamina B17, naenergetyzowana woda. Poczet polskich znachorów, 30 March 2019, at <https://www.newsweek.pl/polska/ hubert-czerniak-jerzy-jaskowski-zbigniew-nowak-tadeusz-ceglinski-jerzy-zieba/kmrztbp > .

Kruse M., Trump Reclaims the Word 'Elite' With Vengeful Pride, 11 December 2018, at <https:// www.politico.com/magazine/story/2018/11/01donald-trump-elite-trumpology-221953>.

Kunce A., Tożsamość i postmodernizm, Warszawa 2003.

Kwapis K., Brygoła E., “Tożsamość osobista w ujęciu emotywno-refleksyjnym: zawartość, funkcje i procesy kształtowania tożsamości”, Opuscula Sociologica, vol. 4, no. 6 (2013).

Lilla M., Koniec liberalizmu, jaki znamy, s. 1. s. a.

Marchlewska M. et al., "Populism as Identity Politics: Perceived Ingroup Disadvantage, Collective Narcissism and Support for Populism”, Social Psychological and Personality Science, vol. 9, no. 2 (2017), https://doi.org/10.1177/1948550617732393.

Matyja H., "Medycyna niekonwencjonalna na granicy prawa na przykładzie 'badania żywej kropli krwi”, Medyczna Wokanda, no. 10 (2018).

"Medycyna niekonwencjonalna", in Internetowa encyklopedia PWN, at <www.encyklopedia. pwn.pl/haslo/medycyna-niekonwencjonalna;3939273.html>.

Miller W.L., Crabtree B.F., “Badania kliniczne”, in N.K. Denzin, Y.S. Lincoln (eds.), Metody badań jakościowych, vol. 1, Warszawa 2014.

Minkner K., "Polityczność teorii spiskowych”, in M. Mikołajczyk, M. Karwat (eds.), Politologii model krytyczny, Kraków 2017.

Mouffe C., W obronie lewicowego populizmu, Warszawa 2020.

Müller J.-W., Co to jest populizm?, Warszawa 2017. 
Naturoterapia. Znachorstwo czy alternatywna metoda leczenia?, at <dziendobry.tvn.pl/a/ naturoterapia--znachorstwo-czy-alternatywna-metoda-leczenia>.

Nigel Farage: People Have Had Enough of Out of Touch Elites, 12 September 2016, at <https:// www.foxbusiness.com/politics/nigel-farage-people-have-had-enough-of-out-of-touch-elites $>$.

Norris P., Inglehart R., Cultural Backlash. Trump, Brexit and Authoritarian Populism, New York 2018, https://doi.org/10.1017/9781108595841.

Nowakowska L., "W stronę socjologii lecznictwa niemedycznego - zarys przedmiotu badań", Hygeia Public Health, vol. 47, no. 3 (2012).

Oliver J.E., Wood T., "Medical Conspiracy Theories and Health Behaviors in the United States", JAMA Internal Medicine, vol. 174, no. 5 (2014), https://doi.org/10.1001/ jamainternmed.2014.190.

Pakulski J., "Ruchy populistyczne i degeneracja elit przywódczych - analiza weberowska", Zoon Politikon, no. 7 (2016).

Paleczny T., Kontestacja: formy buntu we wspótczesnym spoteczeństwie, Kraków 1997, at <https://www.uj.edu.pl/documents/3337228/86fad7e3-4a88-44a5-b1d9-f669630c9084>.

Pilarska A., Ja i tożsamość a dobrostan psychiczny, Poznań 2012.

Ptaszek G., "Wróżba (telewizyjna) jako narracja. Prolegomena”, in J. Wasilewski (ed.), Narracje w życiu. O grupie i jednostce, Warszawa 2016.

Reportage "Uwaga TVN" about Jerzy Zięba, at < uwaga.tvn.pl/reportaze,2671,n/jerzy-zieba-ijego-ukryte-terapie-kulisy-slawy,218161.html >.

QAnon: Trump lauds bizarre conspiracy theory, 20 August 2020, at <https://www.bbc.com/ news/av/world-us-canada-53844108>.

Sakowski Ł., 'Ten cztowiek szkodzi ludziom'. Mówia ofiary Jerzego Zięby, at <www.newsweek.pl/ polska/spoleczenstwo/ofiary-jerzego-zieby-opowiadaja-pod-nazwiskami-o-jego-terapiach/ hzb8y62>.

Sathyanarayana Rao T.S., Andrade C., The MMR Vaccine and Autism: Sensation, Refutation, Retraction, and Fraud, at <www.ncbi.nlm.nih.gov/pmc/articles/PMC3136032/>.

Scott M., QAnon, wielka amerykańska teoria spiskowa, zyskuje setki tysięcy zwolenników w Europie, 26 October 2020, at <https://wiadomosci.onet.pl/politico/teorie-spiskowe-qanonzyskuje-setki-tysiecy-zwolennikow-w-europie/kcwdxj7>.

Skandaliści - Jerzy Zięba, at <www.polsatnews.pl/wideo-program/skandalisci-jerzy-zieba_ $6677102 />$.

Słonecki J., Zdrowie na wtasne życzenie, Katowice 2004.

Speeches delivered during parliamentary sessions, Session 4 on 22 January 2020 (day 1), G. Braun, at <http://search.sejm.gov.pl/SejmSearch/ADDL.aspx?SelectResult>.

Stachowski R., "Karl Popper i Frank Cioffi. Dwa spojrzenia na pseudonaukę”, in K. Korab (ed.), Pseudonauka. Choroba, magia czy biznes?, Warszawa 2011.

"Stosunek do szczepień ochronnych dzieci. Komunikat z badań", Centrum Badania Opinii Spotecznej, no. 9 (2019), at <https://cbos.pl/SPISKOM.POL/2019/K_009_19.PDF>.

Ten Threats to Global Health in 2019, at <www.who.int/emergencies/ten-threats-to-globalhealth-in-2019>.

Thorwald J., Dawna medycyna. Jej tajemnice i potega, Warszawa 2017. 
Tokarz M., Argumentacja. Perswazja. Manipulacja. Wyktady z teorii komunikacji, Gdańsk 2006.

Tombak M., Uleczyć nieuleczalne, part 1, Łódź 2000.

Vaccine Skeptic Robert Kennedy Jr. Asked to Head Trump 'Vaccination Safety' Committee, at <https://www.medicinenet.com/script/main/art.asp?articlekey=200826>.

Waszczyńska K., "Wokół problematyki tożsamości”, Rocznik Towarzystwa Naukowego Ptockiego, no. 6 (2014).

Wojciechowska R., “Jarosław Kaczyński w Gdańsku. 'W Polsce musi nastąpić wymiana elit”, Dziennik Battycki, 26 August 2014, at <https://dziennikbaltycki.pl/jaroslawkaczynski-w-gdansku-w-polsce-musi-nastapic-wymiana-elit-zdjecia-wideo/ar/3552847>.

Wołek A., "Jak polskie elity oswoiły populizm", Ośrodek Myśli Politycznej, at <https://omp.org. pl/artykul.php?artykul=281\#_ftn11>.

Wolf R., Paleo dieta, Poznań 2010.

Woźniak-Holecka J., Zborowska K., Holecki T., "Medycyna alternatywna jako uzupełniająca forma leczenia chorób nowotworowych w opinii pacjentów onkologicznych", Psychoonkologia, no. 1 (2010).

Zdybel L., Idea spisku i teorie spiskowe w swietle analiz krytycznych i badań historycznych, Lublin 2002.

Zięba J., Ukryte terapie. Czego ci lekarz nie powie, part 1, Rzeszów 2015.

Zięba J., Ukryte terapie. Czego ci lekarz nie powie, part 2, Rzeszów 2016.

\section{Internet sources}

Compilation of all episodes "Alfabet Jerzego Zięby", at <www.youtube.com/watch?v= AoWWqp5NGiQ>.

Jerzy Zięba's website, at <www.jerzyzieba.com>.

Profile "Ogólnopolskie Stowarzyszenie Wiedzy o Szczepieniach STOP NOP”, at <www.facebook.com/stowarzyszeniestopnop/>.

Profile "Ukryte terapie - Jerzy Zięba", at <www.facebook.com/ukryteterapie/>.

Videos: JAK POZBYĆ SIĘ MIAŻDŻYCY Jerzy Zięba, at <www.youtube.com/watch? $\mathrm{v}=3 \mathrm{CA} 8 \mathrm{pJ} 11 \mathrm{rxQ}>$; Ukryte terapie, cz. 1 - Jerzy Zięba - 15 July 2014, at <www.youtube. com/watch?v=4fhezw-8_pM>; Ukryte Terapie, cz. 5 - Cukier - Jerzy Zięba -30 September 2014, at <www.youtube.com/watch?v=leVEDIvjLUo>; JERZY ZIĘBA - ZAKWASZENIE $\dot{Z} O E A D K A$, at <www.youtube.com/watch?v=1 hunhblv9HA>; Ukryte terapie, cz. 2 Jerzy Zięba - 22 July 2014, at <www.youtube.com/watch?v=9J90IVw3vqE > .

Jakub K. Górka - graduated from the Institute of Political Science at the University of Opole (2019) with a degree in Journalism and Social Communication and Information Management in the New Media. Scientific interests: political ideologies, sociology of knowledge, alternative discourses, digital economy and organisation management. Currently manages knowledge of digital processes in a private sector company. 